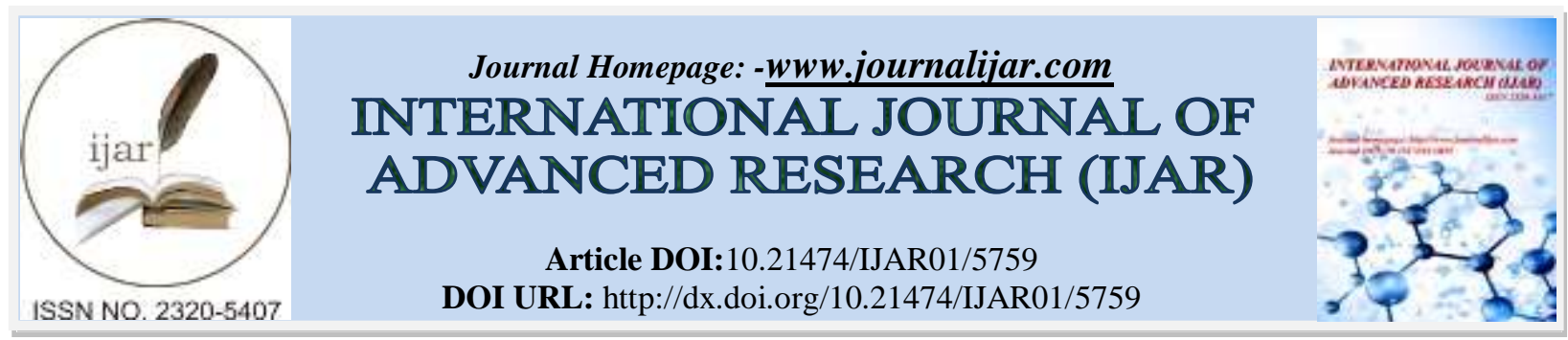

RESEARCH ARTICLE

\title{
REFORMING FOR VALUE CREATING EDUCATION IN PRIMARY SCHOOL KENYA: ADDRESSING POLICY AND PRACTICE.
}

MrsHellenWambui.

Department of Educational Communication \& Technology University of Nairobi.

\section{Manuscript Info}

Manuscript History

Received: 03 September 2017

Final Accepted: 05 October 2017

Published: November 2017

\section{Abstract}

Education and training is a provision that is fundament to governments overall development strategy since January 2003, when the government came power, major reforms to revamp the education sector are being implemented. The reforms cut across the major sub-sectors in education, Primary education, that is early childhood education, Primary education both formal \{and non-formal\} secondary education, Tertiary education A sessional paper is currently being developed by the government which will provide legal framework for the ongoing sectoral reforms. The purpose of the sessional paper will guide education for the next 20 years and will provide policy guidelines that will provide ensure every Kenyan the right to education and training no matter his or her socio, economic status. The objective of the reforms is to improve access, equity, quality and relevance of education and training at all levels. National policies are indeed the road maps of practices in education in any county; however, the degree to which they succeed will depend on certain variable; environment, resources, political, economic capacity and the implementation process. Kenyan, education has been guided by policy guidelines since independence. Policy documents have been in the forms of commissions, presidential working parties, committees and developments plans to guide education practices. To enhance clarification, Policy is a government statement of interest to carry out an activity. The nature of policy also provides standardization, uniformity and gives confidence to service provider. At the same times, policy, when published, assures the client of unbiased service through standardization and uniformity. The findings of the present study will be current curricular reforms which are geared towards competency-based learning. At the core of competency -based learning is the promotion of national valves and principles of good governance for sustainable development. I demonstrate how such decisions have interfered in the running of education. I argue that these political decisions have marginalized the role and contribution of professionals and thus impacted negatively on policy formulation and implementation. My contention is that ideas of politicians are privileged even when they are shallow and myopic. I therefore blame politicians for the crises in the education sector in Kenya today.

Copy Right, IJAR, 2017,. All rights reserved. 


\section{Background to the study:-}

The motivation to focus on reforming education for value creating is threefold; first, and foremost, since independence there have been education reforms and their recommendations have not been implemented hence not served Kenyans adequately. Secondly, 8-4-4 system of education reform was done in 1985; Kenyans are still calling for change to the education system to be relevant to the needs of Kenyans. The question everyone is asking is where is the problem? Thirdly, since independence we have reformed education system as follows; in 1964 Africanization and National goals of education (GOK, 1964), in 1976 national objectives of education and policies in Kenya (GOK, 1976); in 1981 the establishment the Second University (GOK, 1981), in1988 working party on education and training for the next decade and beyond (GOK, 1988), in 1999 Koech Report (GOK, 1999), Totally Integrated Quality Education and Training (TIQET), but still there are challenges of relevance of education, educated unemployment, Kenyans are still yearning for change in education and they have also resisted the changes in education why?

Despite the Kenya's government efforts towards the realization of Education For All (EFA), it continues to experience a number of challenges. These include gender, responsibility, equity and value creating education, poverty level, human dignity and value creating education, teacher quality, integrity and value creating education, HIV/AIDS pandemic and value creating education, financial support, inclusiveness and value creating education and Kenya's Vision 2030 and value creating education.

\section{Statement of the problem:-}

Despite the Sessional paper, looking at the history of the policy documents that have guided education since independence in 1963 to date, the policies where the Ominde Report of 1964 recognized education as a basic human right and a powerful tool for human resource and national development. While the Kamunge Report of 1988 focused on improving education financing, quality and relevance. The government is emphatic on certain issues and states that "it will take affirmative action to compensate for historical and emerging inequalities and disparities in all areas in "nation building". This is a very powerful statement that implies major changes in practice if the political will for success is to prevail. Unfortunately, current practice is still far from reflecting the policy intentions and there are other policies in operation that seem to negate the same spirit of equity creation. Policies have therefore a long tradition in guiding the government to implement it.

Factors that influence educational development in any country include historical, geographical, technological, religious, political and ideological. Though in Kenya these factors are considered, the political factor is seen as the steering wheel of education in the country. Development of education in colonial Kenya was politically directed. The same trends were realized in post independent Kenya. It is in this view that the study reforms that when looked into can reform education sector to better education in Kenya. The study revealed the positive and negative attributes of certain reforms that have greatly affected Kenyan education.

\section{Gender, equity and value creating education:-}

Vision 2030 mainstreams gender equity in all aspects of society. In regard, gender equity will be addressed by making fundamental changes in four key areas, namely: opportunity; empowerment; capabilities; and vulnerabilities. Women are disadvantaged in accessing labour markets and productive resources. Women have been disempowered at household, community and national levels. They are also under -represented in social and political leadership. The capabilities of women have also not developed to full potential due to limited access to capital, education training and health care. Many Kenyans \{particularly women.\} are exposed to vulnerabilities from civil and domestic violence, economic shocks and environmental hazards. Although some progress has been made in addressing genders disparities, a lot of effort still needs to be made. Furthermore, given that women play a critical role in the socio - economic development of any nation, there is an urgent need to remove all obstacles that hinder their contribution to national development. Under this vision, specific policy measures will be taken to correct the glaring gender gaps in access to and control of resources, economic opportunities, and in power and political voice. In Kenya enrollment in education has greatly increased over the years. During the last decades of colonial rule, 1943-1963. It is estimated that girls took up just $25 \%$ of all children enrolled in the workforce. In1953, only one woman, of $6 \%$ of all students, achieved post secondary education.

According to UNICEF, the enrollment has increased and the gender gap has reduced in size. UNICEF estimates as of 2012, 83.2\% of youth ages 15-24 literate, in 1973, the girls made up of 43\% of total primary school enrollment. 
In the educationally advanced distrust, this purse chose $50 \%$, and the dues. A pastoral areas and coasts province was blows $32 \%$. UNICEF states females is activity higher than males in primary schools, $84.5 \%$ enrollments compared to $83 \%$ to of primary school is high 96.1 The disparities are in secondary education giving $51.6 \%$ male and $48.4 \%$ to females. Gender disparity according to UNICEF exists among the poorest quintile group of Kenyan of $33.1 \%$ and $25 \%$ females respectively.

The girl child continues to be in vulnerable situation. Parental gender bias, cultural norms, negative impacts of HIV/AIDS pandemic and poverty continue to impact adversely on the girl child's participation in education. The world has made continuous progress towards gender parity showing that gender differences in education can be overcome through public policy and changes in attitude, but there is still a long way to go as only 59 out of 176 countries have achieved gender parity in both primary and secondary education. Gender equality in educational opportunities and outcomes is the most challenging to achieve and is inherently more difficult to measure. Clearly much remains to be done. Many Sub-Saharan Countries (Kenya inclusive) have miles to go before they achieve gender parity and equity in education (EI, 2009).

Future prospects on the girl child education depends on the following factors if EFA goals are to be realized: added commitment by all the stakeholders to the girls education, enough and targeted funding by government and donors to the girl child education, strengthening the gender unit by allocating enough financial and material resources, strengthening the capacity of the National Task Force on Gender and Education by allocating financial resources for activities, incorporating gender programmes in pre-service and in-service teacher training, advocacy for the girl child education be intensified, appointment of more women in key administrative positions at school and policy making level, strategies and plans to address the major disparities identified at primary and secondary school level be formulated (UNESCO, 2000).

Table:- Illustrating the enrolment at Primary, Secondary and Adult Literacy level

\begin{tabular}{|c|c|c|c|c|c|c|c|}
\hline \multicolumn{3}{|c|}{ Primary Education Enrolment } & \multicolumn{2}{c|}{ Secondary Education Enrolment } & \multicolumn{2}{c|}{$\begin{array}{c}\text { Adult Literacy (5 and } \\
\text { Over) }\end{array}$} \\
\hline M & F & GPI & M & F & GPI & M & F \\
\hline $82 \%$ & $83 \%$ & 0.01 & $51 \%$ & $48 \%$ & 0.94 & $91 \%$ & $84 \%$ \\
\hline
\end{tabular}

Source: EFA Global Monitoring Report Statistical table (school year ending in 2009)Girls’ education:

Over the last decade, Kenya has made significant progress in education, achieving gender parity in primary education enrollment and near parity at secondary level. However, as the above data show, gender parity does not mean that universal access to primary education has been achieved and enrolment in secondary education remains low for both boys $(51 \%)$ and girls $(48 \%)$. This is of a particular concern for girls, as the data imply, over half of secondary school-age girls are not enrolled in secondary education. If certain education reforms are made, this dismal turnout will greatly improve.

\section{Women's literacy:-}

Women's literacy rate has significantly increased as a result of positive government policies and strategies. However, despite progress in education as a whole, gender disparity remains a challenge as $16 \%$ of women in Kenya still lack basic literacy skills, compared with $9 \%$ of men. The failure to promote and retain girls in secondary education is probably affecting negatively the slow progress in women's literacy.

\section{Poverty Levels, human dignity and value creating education:-}

Poverty reduction, and reduced income disparities: The objective under this thrust is to reduce inequality in access to public services and income opportunities across gender, social status and regions. The specific goal will be to reduce the national poverty ratio from the current 46 per cent to a rise of between 30 and 35 per cent by 2012. Key strategy to attaining this to target more income -earning opportunities for disadvantaged groups and regions (as identified above) in the six growth sectors of tourism, agriculture, wholesale and retail trade, manufacturing, BPO and financial services. There will also be increased infrastructure spending in the sub-sectors of roads, water, sewerage, community, electricity and lighting targeting poor communities and regions. These measures will be aimed at creating an enabling environment for poor communities to take part in wealth creation for themselves and their country. 
Poverty in Kenya is a complex paradox which requires an in-depth look to appreciate and understand. In 2013 , this East African Nation of about 40 million was ranked $145^{\text {th }}$ among 186 countries in terms of Human Development Programme. The index ranks countries around the world in terms of standards of living, life expectancy and educational attainment.

Most countries were hopeful that opportunities provided by strengthened democratic governance, and improving economies will accelerate progress. However, poverty levels still remain high. On becoming a republic in 1964, Kenyan leaders vowed to eradicate poverty, disease and illiteracy. Today the proportion of the population living on less than one US dollar a day, that is the poverty line, is higher than ever before (Sisule, 2001). With high poverty line, compounded by economic crisis, prevalence of HIV/AIDS pandemic, it could be just a mere dream to attain Education for all by 2020. Poverty has been recognized as one of the factor that affects education.

\section{Teacher Quality, Integrity and value creating education:-}

Kenya will provide globally competitive and quality education, training and research, for her development. Kenya aims to be a regional center of research and development in new technologies. This will be achieved through: integrating early child-hood education into primary- education, reforming secondary school curricula, modernizing teacher training, developing key programmers for learners with special needs, rejuvenating ongoing adult training programmers, revising the curriculum for university and technical institutes to include more science and technology, and in partnership with the private sector, the Government will also increase funding to enable all these institutions to support activities envisaged under the economic pillar.

Delivery of good-quality education is ultimately contingent on what happens in the classroom, and teachers are in the front line of service. The determinant of educational quality is the teacher. Thus, education can be improved through supply of quality teachers (EI, 2009). This remains the role of the government which estimated that the world will need approximately 18 million additional primary school teachers by 2015 . The most pressing need is in sub-Saharan Africa, where an estimated 3.8 million additional posts be recruited and trained by 2015 . Today, teacher-pupil ratio is still high and teacher demand and supply remain a major issue. Good quality education depends in part on reasonable class sizes and Pupil/Teacher ratios (PTR). Yet the GMR (2008) reveals that there are large regional and national disparities in PTRs. The approximate ceiling PTR usually used is 40:1, but there are large regional and national disparities.

There are a number of factors that affect teacher demand and supply. One of the key factor is teacher motivation which is affected by other inherent factors like salary. According to GMR (2006), many countries face a crisis of teacher morale that is mostly related to poor salaries, working conditions and limited opportunities for professional development. Other problems include the doubtful use of contract teachers and the lack of evidence for introducing performance related pay structures. Kenya is a victim of such. Thus, there is all likelihood that the state of affairs can only persist (as we move towards 2015), hence making the achievement of EFA by 2015 a mere wishful thinking.

In regard to teacher deployment, there is need thus to address equal distribution of primary teachers in sub-counties, carry out registration of all pre-school teachers as a symbol of recognition of ECCDE have all untrained teachers trained through in-service courses, put in place adequate staffing norms at all levels to make maximum use of teachers, define the concept of a teacher as a professional within acceptable professional principles (UNESCO, 2000).

\section{HIV/AIDS, human dignity Pandemic and Value creating education:-}

Kenya's high infant and under five mortality rates could be attributed to the HIV/AIDS pandemic, poverty and the general decline in economic well-being. Maternal deaths are strongly associated with sub-standard health care delivery services, a poor work ethic among health care personal and lack of the necessary medical suppliers at the time of labor, delivery and immediately after birth. There is an urgency to address these issues. For the country to achieve the vision aspirations there is need, firstly, to put in place effective and efficient management of basic and specialized health care.

In addition, the country needs to become more efficient in the overall use of hall resources. One way of doing this is to restructure health care spending towards preventive rather than service. In 2006, 51\% of public sector expenditures, in health with only $5 \%$ dedicated to towards curative health with only $5 \%$ dedicated to preventive 
and promotive health care. This is the patterns the vision aims to reverse. That change will be reinforced by an increase in the number of health careprovides. The country number of health personnel to the population is still inadequate e.g. there are only 14 physicians for every 100,000 people, which is too low. The number of health personnel will be increased and reoriented towards provision health care.

The prevalence of HIV/AIDS has had a significant impact on population of Kenya. The UN estimated that $15 \%$ of adults between the ages of 15- 49 were living with HIV/AIDS in 2001. The AIDS epidemic causes higher death and infant mortality rates, and lowers life expectancy. There has been a rapid spread of AIDS, since 1980s.The HIV/AIDS prevalence was 6.70 per 100 adults in 2003. As of 2004, there were approximately 1,200,000 people living with HIV/AIDS in the country. There were estimated 150,000 deaths from Aids in 2003.

The National Hospital Insurance Fund is the most important health insurance program in Kenya. Membership is compulsory for all civil servants. The government is attempting to improve and upgrade existing health facilities and opening new ones. Kenya produces cotton wadding domestically, but all other medical equipment and supplies are imported. High-quality private practitioners require sophisticated medical equipment, but the public sector acquires less expensive equipment. Kenya also has a well-developed pharmaceutical industry that can produce most medications recommended by the World Health Organization.

The government is attempting to reduce malnutrition and combat deficiency diseases. Among Kenya's major health problems are tuberculosis and protein deficiency, the latter especially among young children. Although the incidence of malaria has been reduced, it still is endemic in some parts of Kenya and is responsible for anemia in children. Water supply, sanitation, bilharzia, and sleeping sickness also pose major problems. Schistosomiasis is endemic to some areas. In $2000,49 \%$ of the population had access to safe drinking water and $86 \%$ had adequate sanitation.

As of 2003, the crude birth rate and overall mortality rate were estimated at 27.6 and 14.7 per 1,000 people respectively. As of 2000, 39\% of married women (ages 15 to 49) were using contraception. Average life expectancy was 47.99 years in 2005 and infant mortality was 61.47 per 1,000 live births. The fertility rate was 4.4 children per childbearing years of a Kenyan woman as of 2000. Immunization rates for children up to one year old were fairly low: tuberculosis, 42\%; diphtheria, pertussis, and tetanus, 36\%; polio, 36\%; and measles, 32\%. Malnutrition affected an estimated 33\% of children under five. As of 2004, there were an estimated 13 physicians, 90 nurses, 2 dentists, and 5 pharmacists per 100,000 people. Health care expenditure was estimated at 7.8\% of GDP. The government was also encouraging the development of the private health care sector through tax incentives as well as other plans.

There has been a rapid spread of AIDS since the 1980s. The HIV/AIDS prevalence was 6.70 per 100 adults in 2003. As of 2004, there were approximately 1,200,000 people living with HIV/AIDS in the country. There were an estimated 150,000 deaths from AIDS in 2003.

In Kenya, the devastating impact of HIV/AIDS on education systems continues to be inadequately addressed in education planning since reduction of poverty level, the wellbeing substandard healthcare issues are yet to be implemented. "the focus has been on curriculum reform in education to include teaching on HIV/AIDS prevention rather than an integrated response aimed at addressing the multiple disadvantages faced by children affected by HIV/AIDS." (GMR), Education systems could play a key role in creating awareness and curbing HIV/AIDs pandemic and thus increasing school enrolment. For instance, in Kenya, access to medicine for families living with HIV/AIDS has improved school attendance.

Many governments in Sub-Sahara Africa have not even developed policies aimed at supporting children who live with HIV or who have lost parents to the disease. AIDS-affected children are failing to go to school because governments are taking too long to implement the policies. In sub-Saharan Africa, there are more than 12 million children orphaned by AIDS, while overall school enrollment rates have risen to approximately $66 \%$ in the continent, AIDS-affected children have been systematically left behind. According to the report, children suffer de facto discrimination in access to education from the moment HIV/AIDS afflicts their family. Children leave school to perform household labor or to bereave their parents' death. Many cannot afford school fees because their parents are too sick to earn a living (HRW, 2005). 
HIV/AIDs has not only have had effect on children but also teachers. HIV-related health problems lead to teacher absenteeism (UNESCO, 2005). Although the government has made certain effort in catering for their needs of the infected teachers, the impact could still be far much reaching in terms of provision of quality education.

\section{Financial support, Inclusiveness and value creating education:-}

The 2030 vision for financial services is to create a vibrant and globally competitive financial sector promoting high levels of savings and financing for Kenya's investment needs. Kenya also intends to become a regional financial services center. This will be achieved through: undertaking legal and institutional reforms to make Kenya more competitive as a financial centre; reforms in the banking sector that will be undertaken to facilitate the consolidation of small banks in Kenya to larger and stronger ones; introduction of credit referencing in the country; streamlining informal finance and savings and credit Co-operative organizations, as well as micro-finance institutions; and deepening financial markets by raising institutional capital through pensions funds, expanding bond and equity markets, as well as tapping international sources of capital.

Central to Kenyan government planning is a continuing expansion of the level of exports and diversification of products. Moreover, Kenya has sought the orderly introduction of large numbers of African farmers into former European agricultural areas. With the goal of full economic independence, the government continues to pursue Africanization of the private sector, particularly in commerce. Kenya continues to assist private industry by tariff structures that permit the import of raw materials duty-free or at low rates; allow rebates or suspension of customs duties under certain conditions; and establish protective customs barriers. The 1979-83 development plan, Kenya's fourth, had as its main objective the alleviation of rural poverty. The 1984-88 development plan also emphasized the rural sector in calling for an annual real GDP growth of $4.9 \%$.

Kenya has depended on external assistance for development financing, but the extent of that dependence has varied with domestic conditions. Whereas in the mid-1960s Kenya depended on external sources for $82 \%$ of its total development resources, by the early 1970s the proportion had fallen to only 45\%. The late 1970s and 1980s brought renewed reliance on external loans, as the proportion of foreign financing needed to cover the annual government budget deficit rose from $28 \%$ in $1978-79$ to $67 \%$ in $1981-82$ and an estimated $89 \%$ in 1985-86. Development in Kenya now depends on the private sector and on foreign and domestic investment as the parastatal sector is dismantled. Foreign exchange earnings were key to the sixth development plan (1989-93). Because of government mismanagement of funds during the period between 1996 and 1999, most development agencies (including the IMF and World Bank) refused to extend loans and gave up on structural reform programs. The government initiated its own Economic Recovery Strategy in 1999 to increase public sector management reliability, but there were doubts as to the effectiveness of the plan.

In 2000, the IMF renewed lending, in the amount of a three-year \$193 million Poverty Reduction and Growth Facility (PRGF) Arrangement, which was further augmented due to the impact of severe drought conditions. An anticorruption authority set up by the government was declared unconstitutional in December 2000, and other Kenyan reforms stalled. The IMF and World Bank once again suspended their programs. In July 2003, the IMF indicated it would resume lending to Kenya, as the Fund was encouraged by the country's efforts to fight corruption and promote good governance.

Financing Education For All (EFA) remains a challenge facing many developing countries. Most of these governments depend upon donor support which more often than not, come with strings attached (EI, 2009). These government and oftenly financially strained due to a number of factors ranging from political and economic instability to weak governance. Thus, they are not able to support sustainable implementation of Education for all. Kenya continues to face a number of challenges following the introduction of Free Primary education in 2003 and Free Secondary Education in 2008. These challenges are mainly associated with lack of adequate teachers (human resources), and equipment and facilities (physical resources) (UNESCO, 2005). The root cause of all these challenges is lack of adequate financial resources. Kenya is not about to be free from its state of 'need', thus pushing for the dream of Education for All by 2015.

Kenya's Vision 2030 and value creating education:-

Kenya transform into a middle-income country providing high quality life to all its citizens by the year 2030 "the vision is based on three "pillars" the economic pillar the social pillar and political pillar (GOK, 2007). The vision's adoption comes after the successful implementation of the Economic Recovery Strategy (CRS) for wealth and 
employment creation. The vision is to be implemented in successive five years' medium term plans thus: 20082012, 2012-2016, 2016-2020, 2020-2024, 2024-2028 and 2028-2030 (GOK, 2007). As the country makes progress to middle income status through this development plans, it was expected to have met its Millennium Development Goals (MDGs) by 2015. Some of these millennium goals in Kenya have been met thus: eradicate extreme poverty and hunger, achieve Universal Primary Education, promote gender equality and empower women. The new World Bank director praised Kenya for Free Primary Education as a pace setter in this education initiative in Africa (this was the first phase of education support frame work from donors. This cash/ donor funds were for reforms in education from early childhood to university. The funds cover technical training, adult education and information technology.

The funding from the budget i.e. 94.4 billion, 534.9 million was to be spent on education reforms (Standard, $31^{\text {st }}$ March, 2005). The transition rate of primary to secondary is $40 \%$ but 2010 it should be $70 \%$. The funds from the government and donors have steered education reforms to start achieving some of the Vision 2030 targets already within the time specified. The Vision 2030 was planned and structured in three pillars namely: Economic, Social and Political pillars. The Economic pillar was to raise Kenyan economic development and standards to all Kenyans. The Economic pillar should bring development targeting agriculture as strategic and Kenyans mainstay. The agricultural education and training from primary, secondary and university should be improved which calls upon education reform to focus on agriculture as the main stay of most Kenyans thus, more than $80 \%$ Kenyans are in rural areas.

To emphasize on the economic pillar, the following areas are key thus: agriculture, environment, financial revenue, systems of finance and ICT in schools and colleges. The government has included these issues in education with a lot of success today. On social pillar, the vision focuses on social services such as education and training, health, gender, youth and urbanization, social welfare and services in the community. Education sector should emphasize these areas in line with Vision 2030. The vision aims to build a just and cohesive society with social equity in a clean and secure environment. The strategy further makes special provisions for Kenyans with various disabilities and previously marginalized communities. These policies and those in the economic pillar are anchored on all round adoption as an implementing tool. These are the targets fronted by education to fulfil the dream of the Vision 2030 in terms of education reforms.

The political pillar aims to realize a democratic political system founded on issue based politics that respects the rule of law and protects the rights and freedoms of every individual in Kenyan society. The pillar hopes to transform equality in Kenya irrespective of one's race, creed, ethnicity, religion, gender or social economic status; a nation that respects and harness the diversity of its people's values, traditions and aspirations for the benefit of all citizens. The pillar deals with leadership, governance i.e. arms of government, judiciary, legislative and executive. Are the arms of government working based on the constitution, law and independent thus separation of powers.

The leadership of this country, the political class and parties must reform to improve the situation in this country. The leadership must reform to avoid the worst happenings like those happening in the Arab world and West Africa. The education systems have political objectives and reforms which are emphasized in line with Vision 2030. The vision for education sector in Kenya for 2030 is, "to have globally competitive quality education, training and research for sustainable development." While the mission for education sector in Kenya is to; "provide, promote, and coordinate the provision of quality education, training and research for empowerment of individuals to become responsible and competent citizens who value education as a lifelong process" (GOK, 2007). To achieve this vision, strategic areas namely; access, quality equity, science, technology and innovation have been identified for support based on their impact on the economic, social and political pillars. Therefore, the Vision 2030 education reform process targets include:;Improve access through increased enrolment ;Reduce illiteracy levels by about $80 \%$; Transition rate must improve in primary to secondary schools from $47 \%$ to $70 \%$ and basic education should include secondary education ; Special needs education should be integrated in school system where schools also admit all students even those with special needs ;Transition rates from secondary education to tertiary education should rise from 3\% to $8 \%$; Expand access in tertiary or university education from $4 \%$ to $20 \%$;Improve quality of education ; Introduce environmental education to protect the environment; Expand teacher education and training For Vision 2030 to fulfil its mandate, teachers are central to any successful implementation of education reforms and change. Kenya presently is experiencing societal changes, so does its needs and aspirations on education system and schools that are expected to be prepared to cope with these changes and also initiate education changes/ reforms in relation to the changing needs of the society. Society change, school read change and act accordingly through a teacher. Therefore, quality of teachers is important for improving and sustaining the quality of teaching and 
education in general for successful implementation of education reforms. Education reforms in school or education system must reach the community and should emanate from the community so that implementation is without resistance.

There is need to increase the relevance of education provided to the youth through environmentally related curriculum reforms based on community needs and conditions. This environment is in physical, social, cultural economic and political spheres which are in the context of Vision 2030. These are the environments that the education curriculum should relate to the community and its needs. For example, the education system has forced schools to phase out subjects or subjects not being taught, meaning that these subjects are not relevant to the community needs. Phasing out subjects in secondary schools such as Business studies, Art and Design, Music, Woodwork and other applied subjects as was done by the Ministry of Education in 2002. This militates against the goal of education i.e. education for national development which cuts across all the pillars of Vision 2030. According to the three pillars, agriculture is central but it's not compulsory in the school system where more than 80 percent Kenyans get their livelihood in agriculture. Moreover, other applied and technical subjects such as Business Studies, Power Mechanics, Electricity, Computer studies have been given very limited space and sometimes removed from the syllabus as it was done in 2002. As UNESCO (2006) observes:

"From January 2003 a new curriculum was implemented to reduce workloads for both teachers and students, and also to align education system to free primary education policy. The curriculum reduced the number of examinable subjects from 7 to 5 at primary schools and 10 to 8 in secondary schools. Between 2002 and 2005 vocational subjects were removed from regular primary and secondary schools following the review of curricular. The Sessional Paper no 1 of 2005 recommended that technical subjects who had been dropped from secondary school curriculum be re-introduced. This was done with immediate effect showing that education reforms are done for innovations" (UNESCO, 2006). Mathematics, sciences and technical subjects are key to industrial and economic development; therefore, the recommendations to remove them from school curriculum had been misplaced.

Sessional Paper No.1of 2005 recommended the return of technical subjects to the school system because of their primary importance for innovation and vision 2030. From policy documents since independence thus from Ominde Report to Koech Report, some of the education reforms and unified curriculum cannot achieve intended goals of the community as expected. For instance, previously, before Sessional Paper no 1of 2005, in Muslim areas such as Coast and North Eastern parts of Kenya, the main religious subject was Christian Religious Education (CRE) and not Islamic Religious Studies (IRE). This is totally different from community needs. In addition, fishing and agriculture taught to mainly pastoral groups of North Eastern and Northern Kenya and yet these environments favors livestock keeping. The curriculum should be environmentally friendly to the community needs hence the community should dictate the reforms in education to meet the community needs and challenges. Relevance of curriculum of education to suit the needs of the Kenyans is paramount.

In Kenya curriculum development is developed by Kenya Institute of Education, it cannot just change the curriculum without involving the community. There has been a belief that traditional education and imported formal education tended to impose thus to be at the middle as a cultural barrier between a child and his community. This meant that on leaving school, the child will find difficulties to reintegrate with the people among whom is to spend the rest of his life because the current 8.4.4 education system is still elitist for white collar jobs in curriculum from the west/ Europe/America because people will reject it. The current 8.4.4 education system was rejected because it was purely Canadian education system brought in Kenya by Mackay 1981 Commission (G.O.K, 1981). Moreover, missionaries brought and introduced formal education (Burgman, 1990) that was not relevant to the Kenyan needs because the formal/ Western Education served European interests in Kenya in the formative years of colonialism. Therefore, Kenya Institute of Education came up to reform education curriculum to suit the Kenyans needs because formal education has been serving colonial interests in post independent Kenya.

There is need to reform the curriculum to suit the needs of Kenyan society. Curriculum changes are affected by the implementation of change and knowledge; to gain knowledge for use? Or for its own sake that is social demand for education. This why Kenyan and other developing countries established bodies known as curriculum development units or centers such as Kenya Institute of Education in Kenya. The activities of these centres are limited, not merely to substitute local African materials for European materials without changing the structure or bias of the curriculum as a whole. However, what is known to be pure is not pure; everything has been modified, changed, transformed or reformed. Kenya Institute of Education is changing what is there with the local or Kenyan materials for instance, the set books from African literary icons like NgugiWaThing'o, Imbuga Francis, Wole Soyinka, and Chinua Achebe 
among others. Kenya Institute of Education is reforming the Kenyan materials to suit the Kenyan needs. Graduates of 8.4.4 are not balanced persons in society. For example, in school we teach them to be independent and make independent decisions and choices.

Consequently, while students may have found their learning more meaningful, the reformed curriculum may have been less academic and functionally irrelevant than the one it replaced. The needs of an individual, when change is the denominator an individual retraces back to the original self since Kenyan needs keep on changing thus retrogressing to the mean. It has been suggested that, a truly community curriculum implies a change over, from one which is structured around various disciplines of knowledge to one based on an analysis of community learning needs. However, such as structure appears less suitable as a preparation for further education hence mastery of discipline may be more fundamentally important. For instance, curriculum development where a person who is to be self employed, this is a terminal co-curriculum 8.4.4. The standard 8 and form four should go to the community to work or to continue with their education/ learning? Currently 8.4.4 is more academic than the practical and technical. For example Bachelor of Education (B.ed) learning leans towards Master of Education.

Therefore the diploma teachers are prepared to teach secondary while the B.ed graduates are prepared to continue with their learning thus master or doctor of education programs. Indeed, the current 8.4.4 education system was launched in 1985 to replace 7.4.2.3 for vocational, technical, practical skills and knowledge. Its objectives were noble for Vision 2030, but the reform process was political power coercive and did not involve people or stakeholders hence people resisted and rejected 8.4.4 education system. Although the Government implemented the Mackay Report of 1981 fully, the Government was not able to convince Kenya to accept the system because it was political rather than educational process hence had various challenges at its inception.

The figure below is illustrating current issue affecting the education sector and the intervening variables which if improved realization of reforms and value creation in education will be achieved. 

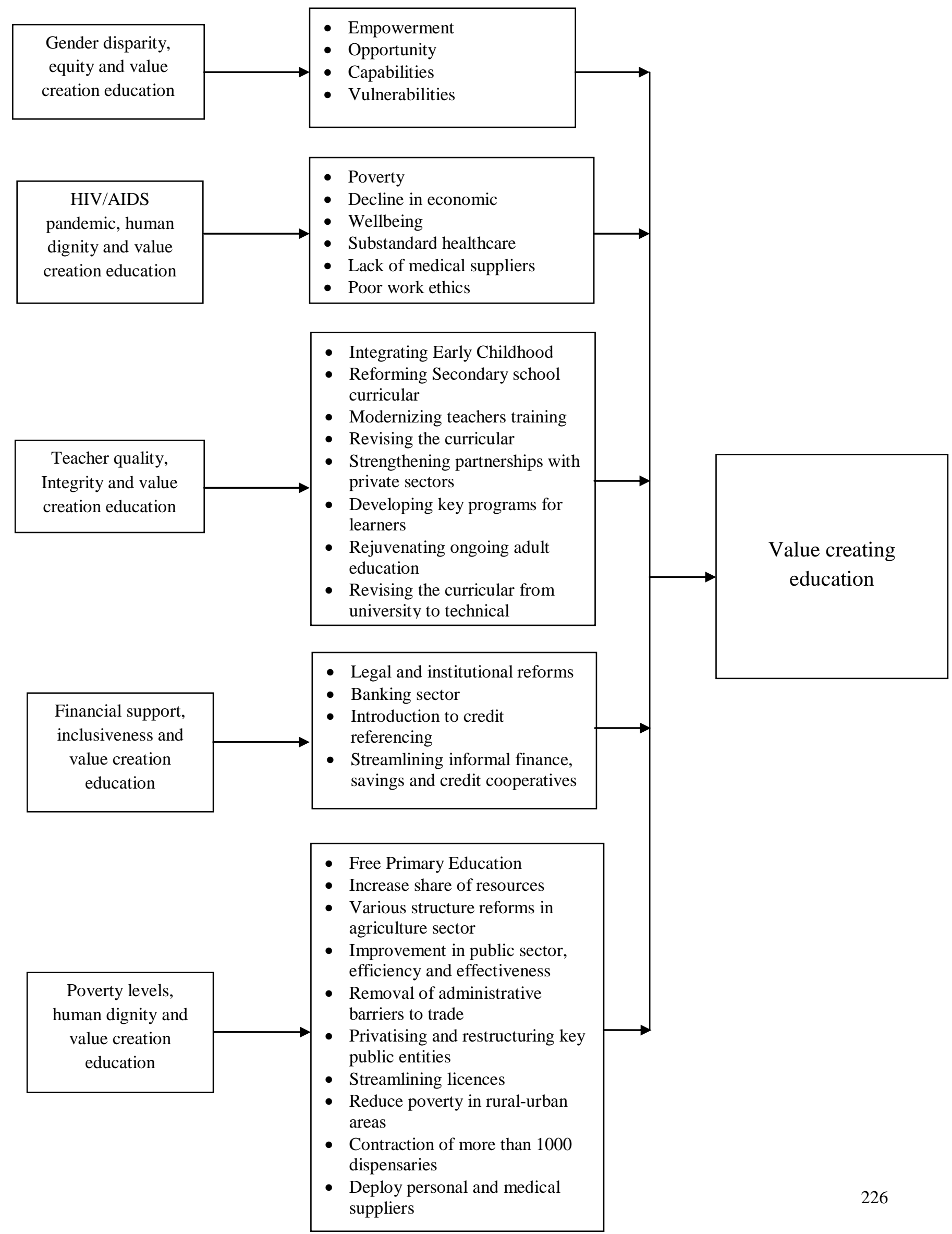


\section{Methodology:-}

Creswell and Plano Clark (2006) provided the definition of mixed methods which served as a guide for this study: Mixed methods research is a research design with philosophical assumptions as well as methods of inquiry. As a methodology, it involves philosophical assumptions that guide the direction of the collection and analysis of data and the mixture of the qualitative and quantitative approaches in many phases in the research process. As a method, it focuses on collecting, analyzing, and mixing both quantitative and qualitative data in a single study or series of studies. Its central premise is that the use of quantitative and qualitative approaches in combination provides a better understanding of research problems than either approach alone.

\section{Type of Design Used and Definition :-}

This study used an Explanatory mixed methods design. The explanatory design is a two-phase mixed methods design. The overall purpose of this is that the qualitative data helps explain or build upon initial quantitative results (Creswell \& Plano Clark, 2006). A variation of the follow-up explanations model was utilized in order for qualitative data to be built upon the initial quantitative results (Creswell \& Plano Clark, 2006).

This method fit nicely into the pragmatic worldview held by this researcher who naturally gravitates toward outcomes and "what works" (Patton, 1990) as opposed to the conditions that concern many other worldviews. Within this pragmatic worldview, it is understood that researchers need to be "free to choose the methods, techniques, and procedures of research that best meet their needs" and that they look to the "what and the how...based on its intended consequences" (Creswell, 2007). The pragmatic worldview served also well in this study, as it enabled the focus to be on methods that not to only provided the best opportunity to uncover the richness of the student-teacher relationship, The administration of the quantitative instrument to all participating students in an upbeat and non-threatening manner served as a prelude that encouraged the students to open up and share their thoughts and feelings in the follow up semi-structured interviews.

\section{Meeting the Challenges of the Design :-}

The explanatory mixed methods design requires a lengthy amount of time for implementing the two phases (Creswell \& Plano Clark, 2006). This timeline fit well within the time constraints imposed by the completion of my doctoral work with regard to the University of Nairobi program. The timeline followed for the completion of my study is explained later in this proposal. The researcher must decide whether to use the same individuals for both phases, or to draw participants from the same population for the two phases (Creswell \&Planork, the researcher must decide which quantitative results need to be further explained (Creswell \& Plano Clark, 2006).

\section{Conclusion:-}

From the findings of this study, education is a key to any nation`s development and for it to play this role, education reforms should be inclusive, clearly planned, protected from political dictates, owned by stakeholders, adequately financed, subjected to periodic technical consultations, full implementation of the commission`s recommendations to achieve innovation. Secondly, education reform is for innovation especially the recent education reforms in Kenya, are realizing the vision 2030 if there is political goodwill by the Government of the day, the stakeholders in education get together, plan for the reform, handle the process together, implement the reforms as a group and based on the technical objectives of the reforms. Education reforms have been handled by the government to achieve political objectives; politicians have handled education reform as a political tool rather than technical process. This led to resistance to reforms in education especially the Mackay Commission of 1981 and the creation of 8-4-4 Education System. This is why Kenyan parents and students have flocked Ugandan schools for 'A' level and colleges such as Bugema University, Kampala University, Busoga and Makerere. This shows that Kenyans are not so happy with education reform of 1981, more so Mackay Commission.

The government in their reform process after independence used power coercive approach to reform education sector without involving other stakeholders. This led to the failure of reform implementation or the implementing agencies used the policy of retrogressing to the mean thus to fight reform or change hence the change did not achieve anything. Moreover, education reforms created more challenges than solving education problems such academically oriented and elitist education for white collar jobs in urban areas, school leaver unemployment up date from 1963 to 2012 which have been thorny issues in education, a power coercive strategy as failed education reform process in Kenya since independence. Politically, the government has used education as a tool to achieve their political objectives hence failed to reform education to benefit the masses. The politicians have had a lot of impact 
in education reform than educationists or professionals or educational planners, which has affected the reform momentum and desire to change which has been resisted by majority in the country. Nevertheless, from 2003 to 2012, the National Alliance of Rainbow Coalition and coalition government had a political will and positive attitude toward education reform, this has led to education reforms through policies such as Sessional Paper no. 1 of 2005, acts of parliament and meetings or conferences to discuss education issues, among them; education reform for current needs such as special needs education, national schools, sanitary towels for girls among others, these reforms have yielded innovations in education in realization of vision 2030. Education reform from Ominde in 1964 to Koech 1999 Commission have developed and articulated national goals of education in line with vision 2030. Moreover, formal education cannot meet the objectives of vision 2030 hence, there is need to change or reform education system towards informal and non-formal system to realize the above objectives.

However, government rejection in the full or partial implementation of education commission reports has been the main blunder by the governments bureaucrats since independence, what Amutabi (2003) and Kivuva (2005), calls "punctuated implementation of education recommendations" in Kenya, political intrigue as the main impediment to education reforms by the political elites in the country. Education reforms focused on the curriculum, process, results and solving problems of the country, but very important stakeholders were left out of the process and planning of reforms. These stakeholders include parents, teachers and students who are the people to carry out and implement the change to get desired results.

Despite the fact that reforms in Kenya are a dictate of the circumstances prevailing at the time such as time, available resource, human, financial, physical and political climate of a country, those to handle and implement the reform are key to the success of the reforms planned in the education system, therefore, the teacher, parents, student and the community are paramount to the success of the reforms in education. Further, Koech Report/reforms have been implemented in piece meal. For instance, there is great access to education (from preschool, primary, secondary and universities through school based learning, e-learning among others in the universities. HIV and AIDS have been emphasized in the syllabuses as well as Information Communication Technology (ICT) in schools. Education at primary level was made free from 2002 and today we have what politicians call "free secondary education" from 2008. As to how "free" it is leaves a lot to be desired. Lastly, languages (Kiswahili, English), Mathematics, science and professional subjects, Information Technology (IT) or ICT have been introduced in schools proving that recent education reforms are for innovation in education in line with Vision 2030.

\section{Recommendations :-}

1. Education reform is a very important process, therefore there is need to take time or plan for gradual change. Change is important than taking a short time to think and implement in education as people will resist change.

2. The Ministry of Education Science and Technology should hold various seminars of education reforms stretching from one county to all 47 counties to involve the masses in the desired change and the political will should be available.

3. To realize Vision 2030 through education the following should be done; first, reform the education system from formal to informal and non-formal, thus expand them and extend education to non-formal schools such as prisons since some people in there are innocent people, to do exams, teach the sick in hospitals or bedridden patients. These will improve access, equity, retention, equality, among others. Improve on co-curricular activities by establishing schools that deal with these activities such as football schools, athletics, drama, theatre, music, fashion industry schools.

4. There is need for education and training for teachers to change/reform because in the formal education there are teachers who are not properly educated but they are educating others. Therefore, quality is compromised hence achieving vision 2030 is a mirage because the quality of teacher is paramount to implement the vision 2030 .

5. A condusive atmosphere for learning and children stay at school as the extension of a family, therefore, reforms should capture teacher education, recruitment, deployment and training. Only train those who are interested in teaching but not what Sifuna (1990) calls "mercenaries in teaching" those who joined teaching after failing to get their first career then landed in teaching. In teacher education, should be integrated with school environment, research methods, teaching practice twice not once as the case before. In this case teacher trainee understand where they will teach thus the school not teaching process only, school attachment, teaching practice since he or she will be teaching at school environment.

6. Performance in schools measured by the mean score is not serving the purpose. For instance, how do we compare results of a well-equipped school (private or government) and a window less structure in the rural area that has never seen electricity? The comparison is not level because of uniqueness of each school, in resources, 
nature of students and other variables. Mathematics and sciences punishes very many students when they fail hence, they think mathematics and sciences are a punishment which has got no relationship, therefore, Kenya National Examination Council (KNEC) using mean score to compare results in primary and secondary must find an alternative measure of school achievement, otherwise mean score has had the following drawbacks; "Cheating in exams, high rates of drop outs, Suicide cases, especially those who fail exams, repeating, extra tuition in school system and other challenges that go with ranking in exams." Therefore, the evaluation should be based on the education system not to one examination.

7. Furthermore, education reform should focus on technical schools to impart knowledge, skills and trades to serve the economy. From these technical schools the country would get thinkers in production that will provide innovation, creating jobs after education, not searching for jobs after school thus job creators rather than job seekers. Moreover, reform must focus on quality education, curriculum, and relevance; broaden the curriculum not basing on science and mathematics alone, as KNEC does in Kenya. Curriculum delivery system should be based on project and inquiry methods not the old lecture method that is a teacher centered and bookish knowledge, "teacher syndrome" in education should be minimized, instead, give emphasis on educational trips, field study, and participatory learning and learner centred, all these are paramount in the realization of Vision 2030. Therefore schools should be developed qualitatively and quantitatively in line with Vision 2030.

8. From independence, there has been a lot of political interference in the education reform process and the education policy making. According to Amutabi (2003) some of the education reforms that show political interference in Kenya`s education sector include; Presidential decrees on harambee school system, free education, school milk programme quota system, 8.4.4 system, centres of excellence, National Youth Service, sanitary towels for girls in schools among others. According to Amutabi they were introduced with little or no input from various stakeholders and were undertaken to respond to certain pressure and crises to wade off public concern. It is no wonder then that many of their reports were discarded immediately the crises waned (Amutabi, 2003) in this case, education reforms were undertaken to serve the political interests than technical and educational needs of the Kenyans. Therefore, education reform process is a technical and to achieve innovation, it should be de-politicized or legislation should be enacted to protect education reforms from political elites, to achieve innovation in Kenya.

\section{References:-}

1. Education International (EI) (2009). Education For All by 2015. Retrieved November 24 from http://www.ei-ie.org/docs/IRISDocuments/Education/

2. Daniel, Sifuna ( 1990), "Development of Education in Africa: The Kenyan Experience". Initiatives Publishers.

3. Furley, O\& Watson, T.(1978)," A history of education in East Africa”. NOK Publishers.

4. George Eshiwani (1993), "Education in Kenya since Independence". East African Publishers.

5. GOK (1976), "Report of the national committee on educational objectives and policies". Government press.

6. GOK (1981), "Report of the presidential working party: second university in Kenya'. Government press.

7. GOK (2001), "The Children Act : Act no. 8'. Government press

8. Government of the Republic of Kenya, (2007), Vision 2030. Ministry of Planning and National Development and the Nationl Economic and Social Council (NESC), Office of the President. Government Press

9. Global Monitoring Report (GMR) (2007). Education for All by 2015 Will we make it? Paris: UNESCO. Retrieved November, 242009 from http://unesdoc.unesco.org/images/0015/001548/154820e.pdf.

10. Human Rights Watch (HRW) (2005). Letting them Fail: Government Neglect and the Right to Education for Children Affected by AIDS. Retrieved November, 20 from http://hrw.org/reports/2005/africa1005

11. Joseph Otiende et al (1992), "Education and Development in Kenya: A Historical Perspective." Oxford University Press.

12. Sisule, T.P. (2002). Poverty in the Eyes of Poor Kenyans: An Insight into the PRSP Process . Tegemeo Institute, EgertonUniversity.

13. Sorobea Bogonko (1992), “A History of Modern Education in Kenya, 1895-1992”.Evans Brothers.

14. UNESCO (2000). The EFA 2000 Assessment: Country Reports. Retrieved November, $20^{\text {th }}$ from http://www.unesco.org/education/wef/countryreports/kenya/rapport_3.html 
15. UNESCO (2005). Challenges of Implementing Free Primary Education in Kenya: Experience from the Districts. UNESCO Nairobi Office, March, 2005. Retrieved November, $20 \quad 2009 \quad$ from http://www.education.nairobi-unesco.org/

16. Maurice Amutabi (2003)". Political interference in the running of education in post independence Kenya: acritical retrospection", \|International Journal of Educational Development 23(2003): 141.

17. MOE, (2007). Elimu Newsletter. Nairobi: Government Printer.

18. MOE, (2008). Inclusive Education: The Way for the Future. Nairobi: Government Printer.

19. Oliver, R.(1965)," The missionary factor in East Africa", Longman

20. Otiato, O. P., (2009). Quality of Education and its Role in National Development; A Case Study of Kenya's Education Reforms; Kenya Studies Review 1,1,133-149. 